\title{
Synthesis, crystallographic, spectroscopic studies and biological activity of new cobalt(II) complexes with bioactive mixed sulindac and nitrogen-donor ligands
}

\author{
Asia M. Shalash ${ }^{\dagger}$ and Hijazi I. Abu Ali ${ }^{* \dagger}$ (1)
}

\begin{abstract}
Four novel complexes $\left[\mathrm{Co}\left(\mathrm{H}_{2} \mathrm{O}\right)_{4}(\mathrm{sul})_{2}\right] \mathbf{1},\left[\mathrm{Co}(2-\mathrm{ampy})_{2}(\mathrm{sul})_{2}\right] \mathbf{2},\left[\mathrm{Co}\left(\mathrm{H}_{2} \mathrm{O}\right)_{2}(1,10-\right.$-phen $\left.)(\text { sul })_{2}\right] \mathbf{3}$ and $[\mathrm{Co}(2,9-$ dimephen $)$ $\left(\mathrm{sul}_{2}\right)_{2} \mathbf{4}$ (sul = sulindac, 2-ampy = 2-amino pyridine, 1,10-phen = 1,10-phenanthroline and 2,9-dimeph = 2,9-dimethyl-1,10-phenanthroline) were prepared and characterized by IR, UV-Visible spectroscopy and magnetic properties. The crystal structures of complexes $\mathbf{1}$ and $\mathbf{4}$ were determined by single-crystal X-ray diffraction. In-vitro anti-bacterial activity for the prepared complexes against Gram-positive (Staphylococcus epidermidis, Staphylococcus aureus) and Gram-negative (Bordetella, Escherichia coli) bacteria and Yeast species (Saccharomyces and Candida) were performed using agar well-diffusion method. Only complex $\mathbf{4}$ showed reasonable activity against yeast. All compounds showed more anti-bacterial activity against Gram-positive bacteria than Gram-negative.
\end{abstract}

Keywords: Cobalt(II) complexes, Nitrogen donor ligands, Sulindac, Anti-bacterial activity

\section{Background}

Cobalt has a significant role in proteins; there are at least eight cobalt-dependent proteins. Moreover, cobalt is needed at the active center of certain coenzymes that are called cobalamins especially cyanocobalamins (Vitamin $B_{12}$ ) which regulates indirectly the synthesis of DNA [1-3].

The first reported study about the biological activity of cobalt compounds was in 1952, where cobalt(III) compounds of bidentate mustard seemed to act as hypoxiaselective agents [4, 5]. Several compounds showed considerable activity against bacteria strains and against leukemia and lymphoma cell lines [6]. Furthermore, cobalt complexes possess in vivo insulin-like properties $[7,8]$, anti-fungal and anti-oxidant activities [9]. Several Co(III) complexes with anti-microbial activities have been reported [10-14]. For instance, a Co(III) complex of

\footnotetext{
*Correspondence: habuali@birzeit.edu; habuali1@yahoo.com ${ }^{\dagger}$ Asia M. Shalash and Hijazi I. Abu Ali contributed equally to this work Department of Chemistry, Birzeit University, P.O. Box 14, West Bank, Palestine
}

the known anti-ulcer drug famotidine turned out to have greater anti-microbial activity against $M$. lysodeikticus and Escherichia coli than the metal free drug [10-14].

Recently, metal(II) carboxylate compounds with nitrogen and/or oxygen-donor ligands have attracted an increasing interest because of their potential biological and chemical activities [15]. The interaction between heterocyclic compounds and metal ions is very important in biological systems such as drugs and vitamins [16]. In previous studies cobalt(II) compounds showed anti-fungal and anti-microbial activities; for example, imidazole2-carbaldehyde semicarbazone was active against yeasts Candida tropicalis and Saccharomyces cerevisiae. Activity was most noticeable against phytopathogenic fungi such as Alternaria or Sclerotinia [17].

$\{(1 \mathrm{Z})$-5-fluoro-2-methyl-1-[4-(methylsulfinyl) benzylidene]-1H-indene-3-yl\}acetic acid known as Sulindac, in the form of potassium salt has a wide spectrum of activity as non-steroidal anti-inflammatory drug (NSAIDs). The chemical classes of NSAIDs comprise phenylalkanoic acids, anthranilic acids, salicylate 
derivatives, oxicams, furanones and sulfonamides [1824]. Sulindac belong to phenylalkanoic acids that are potent NSAIDs for the treatment of inflammatory conditions, such as pain, fever and inflammation. The transition metal coordination with NSAIDs caused many enhanced anti-inflammatory activity [25-27]. Some compounds of NSAIDs that can coordinate with transition metals have been synthesized and tested for their biological and pharmacological activity [28-34], to our best knowledge the synthesized cobalt complexes are the first reported structures, in addition to our previously reported zinc (Fig. 1) sulindac complexes [34].

The synthesis, characterization and anti-bacterial activity of new cobalt(II) sulindac containing complexes with heterocyclic nitrogen based ligands (2-aminopyridine " 2 -ampy", 1,10-phenanthroline "1,10-phen" and 2,9-dimethyl1,10-phenanthroline "2,9-dimphen") are described in the present work. The crystal structures of $\left[\mathrm{Co}\left(\mathrm{H}_{2} \mathrm{O}\right)_{4}(\mathrm{sul})_{2}\right](\mathbf{1})$ and $\left[\mathrm{Co}(2,9\right.$-dimephen $\left.)(\mathrm{sul})_{2}\right](\mathbf{4})$ are also reported.

\section{Results and discussion}

\section{Synthesis of cobalt complexes}

[Cobalt sulindac complex], 1 was prepared by mixing cobalt chloride and potassium sulindac in 1:2 molar ratios with methanol as a solvent. The desired product was obtained as a yellow solid (Scheme 1) and its structure was determined by single crystal X-ray diffraction. The novel mixed ligand cobalt(II) complexes were prepared by adding the appropriate N-donor ligand to complex 1 see (Scheme 2). The physical properties of 1-4 are summarized in Additional file 1: Table S1. Physical properties and yield of Cobalt(II) sulindac compounds.

\section{Crystallographic study}

\section{Crystallographic study of complex 1}

The atomic numbering scheme and atom connectivity for complex $\mathbf{1}$ are shown in Fig. 2. The asymmetric unit of the titled complex, contains a Co(II) cation, two monodentate sulindac groups and four water molecules.

Although the synthetic procedure and the recrystallization process of complex 1 were performed in methanol, a marked preference for coordination of water over methanol was observed and proved by single crystal X-ray determination. This phenomenon might be due to the

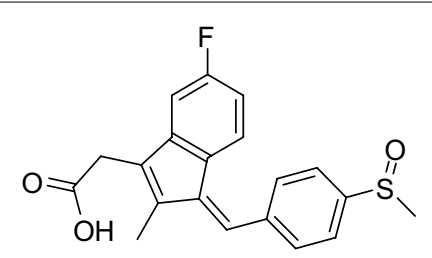

Fig. 1 Sulindac structure [37] stronger bond interaction between water and the metal center than methanol. In addition, the used methanol was not dry enough and wet, so it was possible to provide the four water molecules bonded to the metal center.

The two sulindaco groups are connected to the metal center in a monodentate coordination mode forming a symmetrical octahedral geometry with the additional four water molecules. The $\mathrm{Co}-\mathrm{O}$ bond distances of 2.089(4), 2.100(5) and 2.141(4) $\AA$ are similar to previously reported values [38]. Selected bond angles and bond distances are listed in Table 1.

From the bonding angles in complex 1; O(1)\#1-Co(1)$\mathrm{O}(2 \mathrm{~W}) \# 1=87.9(2)^{\circ}, \mathrm{O}(1)-\mathrm{Co}(1)-\mathrm{O}(2 \mathrm{~W})=87.9(2)^{\circ}$, $\mathrm{O}(1)-\mathrm{Co}(1)-\mathrm{O}(1 \quad \mathrm{~W})=92.09(17)^{\circ}, \quad \mathrm{O}(1) \# 1-$ $\mathrm{Co}(1)-\mathrm{O}(1 \mathrm{~W})=87.91(17)^{\circ}$ and $\mathrm{O}(2 \mathrm{~W}) \# 1-\mathrm{Co}(1)-$ $\mathrm{O}(1 \mathrm{~W})=89.4(2)^{\circ}$ a slight distortion from regular octahedral geometry was observed due to the expected Jahn-Teller effect which is also confirmed by the appearance of a shoulder in the $d-d$ visible transition of this and other cobalt complexes.

\section{Crystallographic study of complex 4}

The atomic numbering scheme and atom connectivity for complex $\mathbf{4}$ are shown in Fig. 3. The asymmetric unit of the titled complex, contains a $\mathrm{Co}(\mathrm{II})$ cation, two sulindac groups and one 2,9-dimephen ligand. The $\mathrm{Co}-\mathrm{O}$ bond distances of 2.117(8), 2.128(6), 2.220(10) and 2.220(10) $\AA$ are similar to reported values [39-47]. Co-N bond distances of 2.090(7) and 2.100(7) $\AA$ are also similar to reported values [39-48]. Selected angles and distances are listed in Table 1.

From bonding angles in complex $\mathbf{4}$, a slight deviation from octahedral geometry was observed, $\mathrm{N}(1)-\mathrm{Co}(1)$ $\mathrm{O}(1)=108.2(3)^{\circ}, \mathrm{N}(2)-\mathrm{Co}(1)-\mathrm{O}(4)=112.3(3)^{\circ}, \mathrm{N}(2)-$ $\mathrm{Co}(1)-\mathrm{O}(5)=102.5(4)^{\circ}, \mathrm{N}(2)-\mathrm{Co}(1)-\mathrm{N}(1)=79.8(3)^{\circ}$ and $\mathrm{N}(1)-\mathrm{Co}(1)-\mathrm{O}(2)=104.3(19)^{\circ}$.

\section{Infrared spectra}

Infrared spectral data of $\mathrm{KBr}$ pellet of cobalt sulindac complexes 1-4 in the $400-4000 \mathrm{~cm}^{-1}$ range are summarized in Additional files 2 and 3: Table S2. Comparison between some of principle peaks in IR for K(sul) and $\mathbf{1}\left(\mathrm{cm}^{-1}\right)$ and Table S3. Summary of principle peaks in IR for complexes 2,3 and $4\left(\mathrm{~cm}^{-1}\right)$. In metal carboxylate complexes, the major characteristic of the IR spectra is the frequency of the $v$ asymmetric $\left(v_{\mathrm{as}}\right)$ and $\mathrm{u}$ symmetric $\left(\mathrm{v}_{\mathrm{s}}\right)$ of carbonyl $\left(\mathrm{COO}^{-}\right)$stretching vibrations and the difference between them $\Delta v\left(\mathrm{COO}^{-}\right)$. The frequency of these bands depends upon the coordination mode of the carboxylate ligand. Monodentate complexes exhibit $\Delta \mathrm{v}\left(\mathrm{COO}^{-}\right)$values that are much greater than the ionic complexes. Chelating (bidentate) complexes exhibit $\Delta \mathrm{v}\left(\mathrm{COO}^{-}\right)$values that are significantly 


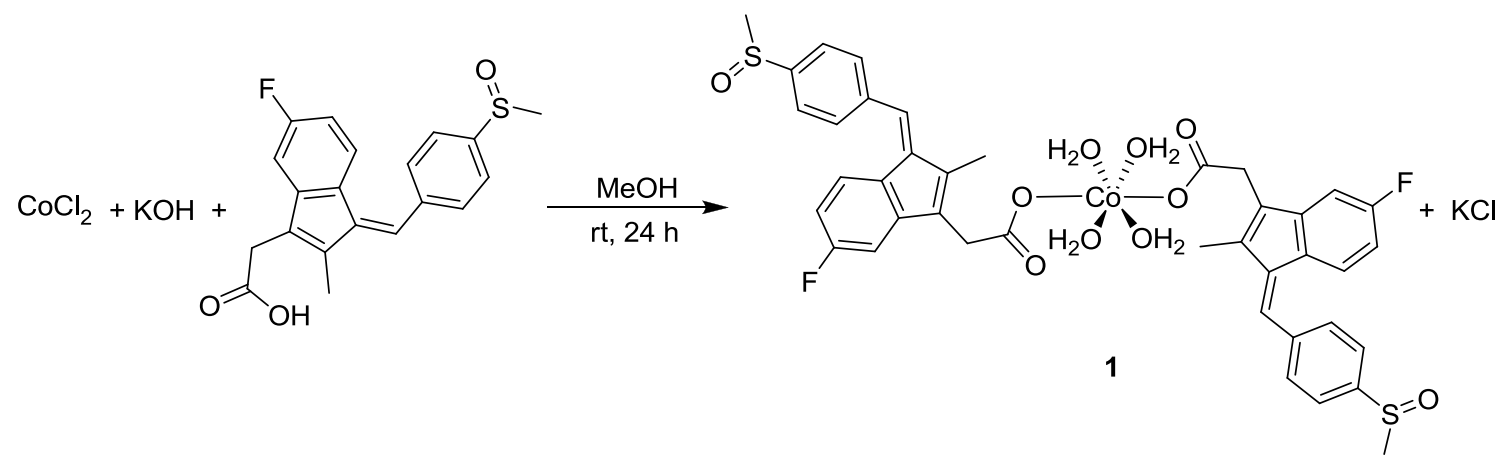

Scheme 1 Synthesis of complex 1

less than the ionic values. $\Delta \mathrm{v}\left(\mathrm{COO}^{-}\right)$values for bridging complexes are greater than those of chelating complexes, and close to the ionic values [49]. In complex 1; $v_{\text {as }}\left(\mathrm{COO}^{-}\right)$is at $1601 \mathrm{~cm}^{-1}$ and $v_{\mathrm{s}}\left(\mathrm{COO}^{-}\right)$at $1397 \mathrm{~cm}^{-1}$, $\Delta \mathrm{v}\left(\mathrm{COO}^{-}\right)=204 \mathrm{~cm}^{-1}$ which is close to that of potassium sulindac which supports a coordination mode for complex $\mathbf{1}$ as monodentate. The $\mathrm{O}-\mathrm{H}$ vibration frequency at $3376 \mathrm{~cm}^{-1}$ indicates the presence of water molecules in the coordination geometry $\left[\mathrm{Co}\left(\mathrm{H}_{2} \mathrm{O}\right)_{4}(\mathrm{sul})_{2}\right]$ as also supported by single crystal X-ray determination.

The assignments of IR frequencies for the asymmetric stretching $v_{a s}\left(\mathrm{COO}^{-}\right)$, the symmetric stretching $v_{s}\left(\mathrm{COO}^{-}\right)$and the difference between these two values of sulindac group in complexes 1-4 and those of potassium sulindac are shown in Additional file 1: Tables S2 and S3.

Complexes 2 and 3 have $v_{\mathrm{as}}\left(\mathrm{COO}^{-}\right)$at 1599, and $1600 \mathrm{~cm}^{-1}$, but $\mathrm{v}_{\mathrm{s}}\left(\mathrm{COO}^{-}\right)$appear at 1390 and $1380 \mathrm{~cm}^{-1}$, so $\Delta v\left(\mathrm{COO}^{-}\right)$are 219 and $220 \mathrm{~cm}^{-1}$, respectively which is larger than $\Delta \mathrm{v}\left(\mathrm{COO}^{-}\right)_{\mathrm{K}(\text { sul })}=178 \mathrm{~cm}^{-1}$ and this supports monodentate coordination mode of the carboxylate groups. In addition, complex $\mathbf{3}$ has an absorption frequency at $3415 \mathrm{~cm}^{-1}$ which may indicate water molecules in the coordination geometry.

Moreover, in complex 2 two absorption frequencies $v_{\text {as }}\left(\mathrm{NH}_{2}\right)$ at $3374 \mathrm{~cm}^{-1}$ and $v_{\mathrm{s}}\left(\mathrm{NH}_{2}\right)$ at $3268 \mathrm{~cm}^{-1}$ with $\Delta v\left(\mathrm{NH}_{2}\right)=106 \mathrm{~cm}^{-1}$ were observed. These frequencies are assigned to the $1^{\circ}-\mathrm{NH}_{2}$ group indicating that the complexation with cobalt is through the pyridine nitrogen atom rather than the $\mathrm{NH}_{2}$ nitrogen atom $[50,51]$.

In complex $4 \mathrm{v}_{\mathrm{as}}\left(\mathrm{COO}^{-}\right)$was observed at $1599 \mathrm{~cm}^{-1}$, and $v_{s}\left(\mathrm{COO}^{-}\right)$was at $1441 \mathrm{~cm}^{-1}$ giving a $\Delta v\left(\mathrm{COO}^{-}\right)$ of $158 \mathrm{~cm}^{-1}$ and this supports a bidentate coordination mode of the carboxylate groups. This result was also confirmed by X-ray structure determination of complex 4 .

\section{UV-Vis spectra}

Generally, three types of electronic transitions have been observed for coordination compounds: Metal to ligand (MLCT) or ligand to metal (LMCT) charge-transfer absorption bands, $d-d$ transition bands and intra-ligand (LC) transition bands $[52,53]$.

$\mathrm{Co}$ (II) metal ion with low spin $d^{7}$ electronic configuration showed two low intensity bands with small $\varepsilon$ value (12-13 $\mathrm{Lmol}^{-1} \mathrm{~cm}^{-1}$ ) in the visible region. The source of these two bands is due to the $d-d$ transition between ${ }^{2} \mathrm{E}^{2} \rightarrow \mathrm{T}_{1 \mathrm{~g}}$ and ${ }^{2} \mathrm{E} \rightarrow{ }^{2} \mathrm{~T}_{2 \mathrm{~g}}$. LMCT was observed at $(206-213 \mathrm{~nm})$ with $\varepsilon$ values between 1800 and $3000 \mathrm{Lmol}^{-1} \mathrm{~cm}^{-1}$ [20, 21, 54-67]. All other bands are similar to nitrogen based ligand $\Pi \rightarrow \Pi^{*}$ or $n \rightarrow \Pi^{*}$ transitions with small blue or red shifts for cobalt coordination complexes [20, 21, 55-67]. The results are tabulated in Additional file 4: Table S4. UV-visible spectral data for compounds (1-4).

Complexes $\mathbf{3}$ and $\mathbf{4}$ adopted distorted octahedral geometries with different carboxylate coordination modes, e.g. monodentate, bidentate, in complex 3 the two water molecules were covalently coordinated to the central $\mathrm{Co}(\mathrm{II})$ cation which imposed monodentate coordination mode of the sulindaco groups. Whereas, the two sulindaco groups in complex $\mathbf{4}$ are both bidentately coordinated to the $\mathrm{Co}$ (II) center as a result of the increased steric hindrance effect by two methyl groups on the 1,10-phen ring. The electronic effect of the ligands in complexes 2-4 are almost identical.

\section{Magnetic properties}

The magnetic moment measurements of compounds 1-4 are given in Table 2. The value of magnetic moments for all complexes indicates that each compound has paramagnetic properties with one unpaired electron, which indicates that each $\mathrm{Co}$ (II) complex adopted a low spin, $d^{7}$ octhedral geometry. Low spin Co(II) octahedral complexes with nitrogen and/or oxygen-donor ligands are very rare [62]. Both structural, magnetic and spectral data are necessary to prove that a complex contains low spin Co(II) metal ion octahedral geometry with only few of these compounds have been structurally characterized by single crystal X-ray crystallography [68-71]. 


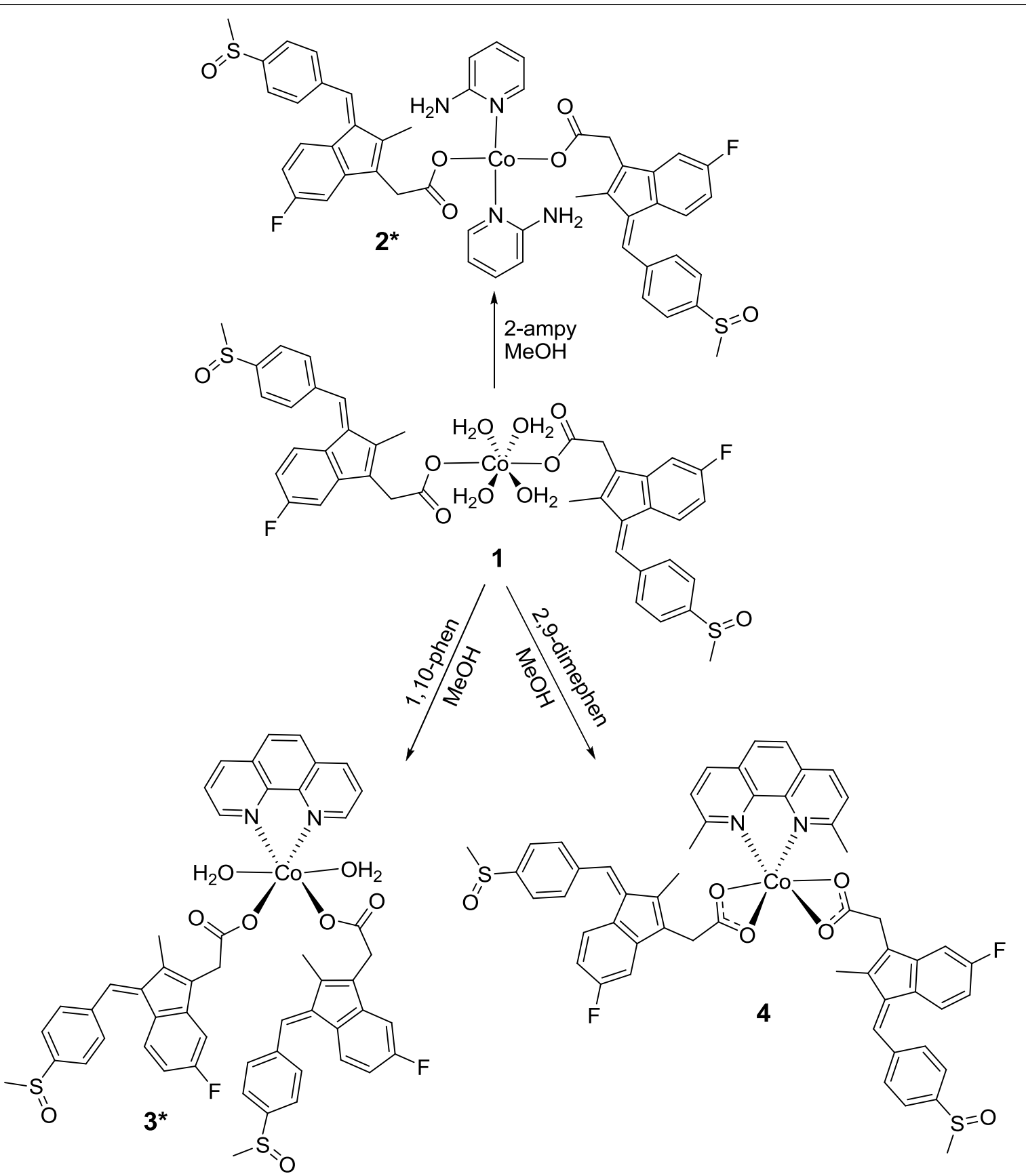

Scheme 2 Synthesis and the proposed structures of complexes 2-4 (Asterisk proposed structure)

\section{Anti-bacterial activity}

Before measurement of their biological activity, the solution stability of the complexes were tested, as the complexes were crystallized by slow solvent evaporation at room temperature that took several days and the same physical properties of the compounds were obtained. Moreover, the relevant X-ray structure determination of some complexes showed that the structures were remained intact.
Two Gram positive bacteria (Staphylococcus epidermidis, Staphylococcus aureus), two Gram negative bacteria (Bordetella, E. coli) and yeast species (Saccharomyces and Candida) were used to test the compounds anti-bacterial activity. The results were obtained by the well-diffusion method using DMSO as a negative control to resist any tested microorganisms; Gentamycin as a positive control for Gram positive and Gram negative bacteria and Nystatin as a positive control for yeast. The parent 


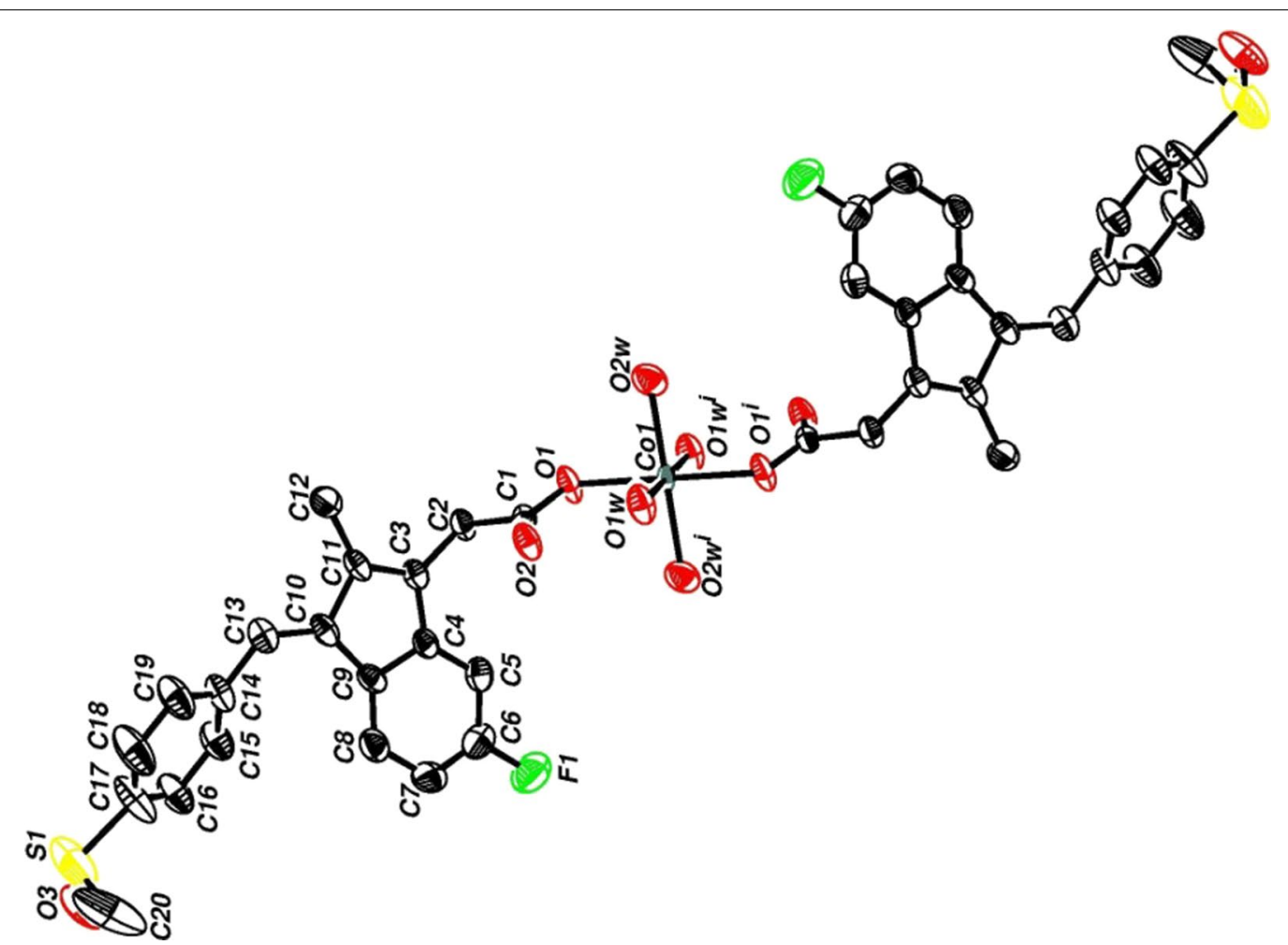

Fig. 2 The molecular structure view of $\mathbf{1}$ showing the atom labeling scheme

Table 1 Selected bond angles $\left(^{\circ}\right)$ and bond distances $(\AA)$ for 1 and 4

\begin{tabular}{|c|c|c|c|}
\hline \multicolumn{2}{|c|}{ Bond distance $(\AA ̊)$ of complex 1} & \multicolumn{2}{|c|}{ Bond distance $(\AA ̊)$ of complex 4} \\
\hline $\mathrm{Co}(1)-\mathrm{O}(1)$ & $2.089(4)$ & $\mathrm{Co}(1)-\mathrm{O}(1)$ & $2.133(7)$ \\
\hline $\mathrm{Co}(1)-\mathrm{O}(1) \# 1$ & $2.089(4)$ & $\mathrm{Co}(1)-\mathrm{O}(4)$ & $2.117(8)$ \\
\hline $\mathrm{Co}(1)-\mathrm{O}(2 \mathrm{~W}) \# 1$ & $2.100(5)$ & $\mathrm{Co}(1)-\mathrm{O}(2)$ & $2.128(6)$ \\
\hline $\mathrm{Co}(1)-\mathrm{O}(2 \mathrm{~W})$ & $2.100(5)$ & $\mathrm{Co}(1)-\mathrm{O}(5)$ & $2.220(10)$ \\
\hline $\mathrm{Co}(1)-\mathrm{O}(1 \mathrm{~W})$ & $2.141(4)$ & $\mathrm{Co}(1)-\mathrm{N}(1)$ & $2.100(7)$ \\
\hline $\mathrm{Co}(1)-\mathrm{O}(1 \mathrm{~W}) \# 1$ & $2.141(4)$ & $\mathrm{Co}(1)-\mathrm{N}(2)$ & $2.090(7)$ \\
\hline \multicolumn{2}{|c|}{ Bond angle $\left(^{\circ}\right)$ of complex 1} & \multicolumn{2}{|c|}{ Bond angle $\left({ }^{\circ}\right)$ of complex 4} \\
\hline $\mathrm{C}(1)-\mathrm{O}(1)-\mathrm{Co}(1)$ & $126.2(4)$ & $\mathrm{C}(1)-\mathrm{O}(2)-\mathrm{Co}(1)$ & $91.5(5)$ \\
\hline $\mathrm{O}(1 \mathrm{~W})-\mathrm{Co}(1)-\mathrm{O}(1 \mathrm{~W}) \# 1$ & $180.000(2)$ & $\mathrm{C}(21)-\mathrm{O}(4)-\mathrm{Co}(1)$ & $94.2(7)$ \\
\hline $\mathrm{O}(2 \mathrm{~W})-\mathrm{Co}(1)-\mathrm{O}(2 \mathrm{~W}) \# 1$ & $180.000(1)$ & $\mathrm{C}(21)-\mathrm{O}(5)-\mathrm{Co}(1)$ & $87.6(7)$ \\
\hline $\mathrm{O}(1)-\mathrm{Co}(1)-\mathrm{O}(1) \# 1$ & $180.000(2)$ & $N(2)-C o(1)-N(1)$ & 79.8(3) \\
\hline $\mathrm{O}(1) \# 1-\mathrm{Co}(1)-\mathrm{O}(2 \mathrm{~W}) \# 1$ & 87.9(2) & $\mathrm{N}(1)-\mathrm{Co}(1)-\mathrm{O}(1)$ & 108.2(3) \\
\hline $\mathrm{O}(1)-\mathrm{Co}(1)-\mathrm{O}(2 \mathrm{~W})$ & $87.9(2)$ & $\mathrm{N}(2)-\mathrm{Co}(1)-\mathrm{O}(4)$ & 112.3(3) \\
\hline $\mathrm{O}(1)-\mathrm{Co}(1)-\mathrm{O}(1 \mathrm{~W})$ & $92.09(17)$ & $\mathrm{N}(1)-\mathrm{Co}(1)-\mathrm{O}(2)$ & 104.3(3) \\
\hline $\mathrm{O}(1) \# 1-\mathrm{Co}(1)-\mathrm{O}(1 \mathrm{~W})$ & $87.91(17)$ & $\mathrm{N}(2)-\mathrm{Co}(1)-\mathrm{O}(5)$ & $102.5(4)$ \\
\hline \multirow[t]{4}{*}{$\mathrm{O}(2 \mathrm{~W}) \# 1-\mathrm{Co}(1)-\mathrm{O}(1 \mathrm{~W})$} & $89.4(2)$ & $\mathrm{O}(4)-\mathrm{Co}(1)-\mathrm{O}(1)$ & $155.4(3)$ \\
\hline & & $\mathrm{O}(2)-\mathrm{Co}(1)-\mathrm{O}(5)$ & 91.9(4) \\
\hline & & $\mathrm{O}(2)-\mathrm{Co}(1)-\mathrm{O}(1)$ & $59.1(3)$ \\
\hline & & $\mathrm{C}(1)-\mathrm{O}(1)-\mathrm{Co}(1)$ & $90.7(5)$ \\
\hline
\end{tabular}




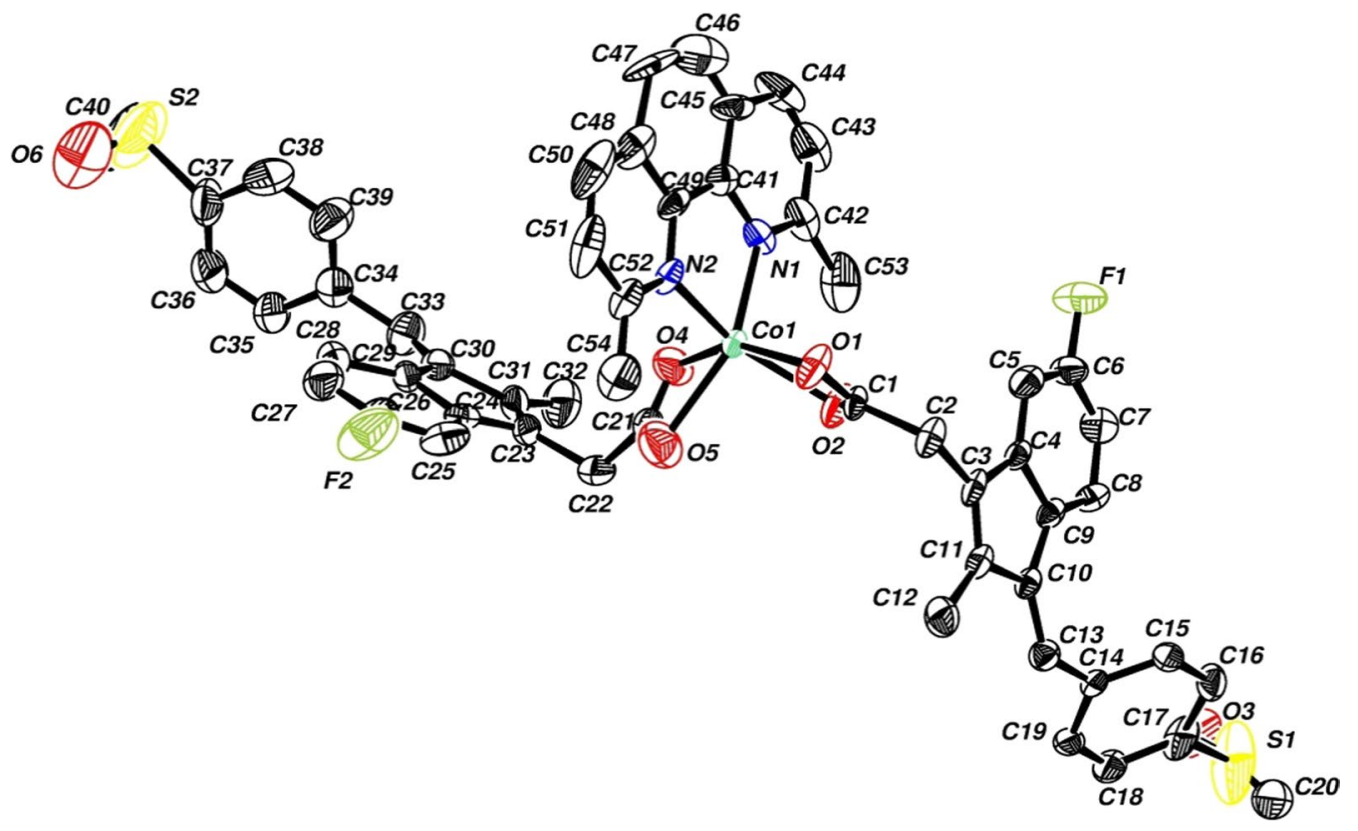

Fig. 3 The molecular structure view of $\mathbf{4}$ showing the atom labeling scheme

Table 2 Magnetic properties of cobalt(II) compounds

\begin{tabular}{lll}
\hline Compounds & $\begin{array}{l}\text { Magnetic moment } \\
\left(\boldsymbol{\mu}_{\text {eff }} \mathbf{B M}\right)\end{array}$ & $\begin{array}{l}\text { Unpaired } \\
\text { electron }(\mathbf{n})\end{array}$ \\
\hline$\left[\mathrm{Co}\left(\mathrm{H}_{2} \mathrm{O}\right)_{4}(\mathrm{sul})_{2}\right](\mathbf{1})$ & $2.26 \pm 0.05$ & 1 \\
{$\left[\mathrm{Co}(2-\mathrm{ampy})_{2}(\mathrm{sul})_{2}\right](\mathbf{2})$} & $2.41 \pm 0.15$ & 1 \\
{$\left[\mathrm{Co}\left(\mathrm{H}_{2} \mathrm{O}\right)_{2}(1,10-\right.$ phen $\left.)(\mathrm{sul})_{2}\right](\mathbf{3})$} & $2.40 \pm 0.12$ & 1 \\
{$\left[\mathrm{Co}(2,9-\right.$ dimephen $\left.)(\mathrm{sul})_{2}\right](\mathbf{4})$} & $2.40 \pm 0.09$ & 1 \\
\hline
\end{tabular}

ligand, potassium sulindac, did not show anti-bacterial activity against any of the tested microorganisms, but $\left(\mathrm{CoCl}_{2}\right)$ showed anti-bacterial activity against all tested microorganisms (Table 3 ).
Complex 1 showed high activity against $\mathrm{G}^{-}$or $\mathrm{G}^{+}$bacteria except against E. coli. Complexes $\mathbf{3}$ and $\mathbf{4}$ showed low activity against $\mathrm{G}^{-}$bacteria and high activity against $\mathrm{G}^{+}$bacteria. Complex 2 showed high activity against $S$. epidermidis and low or zero activity against other bacteria. However, in yeast all complexes didn't show any activity except complexes $\mathbf{4}$ showed high activity. Complexes $\mathbf{3}$ and $\mathbf{4}$ were chosen for further studies because of their higher IZD values. The complexes have been studied with their parent nitrogen donor ligands " 1,10 phen and 2,9-dimephen" against all tested Gram-positive, Gram-negative bacteria and yeast to determine the effect of the complexation on anti-bacteria activity (Tables 4,5 ).

Table 3 In-vitro anti-bacterial activity data of complexes 1-4

\begin{tabular}{lllllll}
\hline Compounds & $\begin{array}{l}\text { Bordetella } \\
\text { G- }\end{array}$ & $\begin{array}{l}\text { E. coli } \\
\text { G- }\end{array}$ & $\begin{array}{l}\text { S. epi } \\
\text { G+ }\end{array}$ & $\begin{array}{l}\text { S. aureus } \\
\text { G+ }\end{array}$ & $\begin{array}{l}\text { Candida } \\
\text { Yeast }\end{array}$ & $\begin{array}{l}\text { Saccharomyces } \\
\text { Yeast }\end{array}$ \\
\hline$(\mathbf{1})$ & $15.3 \pm 0.5$ & $10.1 \pm 0.4$ & $21.0 \pm 0.4$ & $19 \pm 1$ & - & - \\
$(\mathbf{2})$ & $13 \pm 1$ & - & $23 \pm 1$ & $11 \pm 1$ & - & - \\
$(\mathbf{3})$ & $12 \pm 2$ & $8.5 \pm 1.5$ & $26.7 \pm 0.6$ & $21 \pm 1$ & - & - \\
$(\mathbf{4})$ & $16 \pm 2$ & $12 \pm 2$ & $39 \pm 1$ & $25.0 \pm 1.5$ & $42 \pm 1$ & $41.12 \pm 0.5$ \\
$\mathrm{CoCl}_{2}$ & $22 \pm 2$ & $12 \pm 2$ & $30.0 \pm 0.5$ & $11 \pm 1$ & $20.0 \pm 0.7$ & $22 \pm 1$ \\
Sulindac & - & - & - & - & - & - \\
Genta. & $30 \pm 1$ & $37 \pm 1$ & $28 \pm 1$ & $32.7 \pm 0.6$ & - & - \\
Nes. & - & - & - & - & $35.5 \pm 0.2$ & $40.5 \pm 0.4$ \\
\hline
\end{tabular}

Inhibition zone diameter (IZD) in $\mathrm{mm}$, all microorganisms were resistant to DMSO. The data stated as average \pm standard deviation (N $=3$ ), the concentration of the complexes and the standards was $30 \mathrm{mg} / 5 \mathrm{~mL}$ in DMSO $(6 \mathrm{~g} / \mathrm{l})$

- dashes indicated zero inhibition 
Table 4 Comparison of anti-bacterial activity of complex 3 with 1,10-phen

\begin{tabular}{lllll}
\hline $\begin{array}{l}\text { Concentration } \\
\text { (mg/ml) }\end{array}$ & $\begin{array}{l}\text { Bordetella } \\
\text { G- }\end{array}$ & $\begin{array}{l}\text { E. coli } \\
\text { G- }\end{array}$ & \multicolumn{1}{l}{$\begin{array}{l}\text { S. epidermidis } \\
\text { G+ }\end{array}$} & $\begin{array}{l}\text { S. aureus } \\
\text { G+ }\end{array}$ \\
\hline IZD of $\mathbf{3}(\mathrm{mm})$ & & & & \\
$\mathbf{8}$ & $11.9 \pm 2$ & $8.5 \pm 1.5$ & $26.7 \pm 0.6$ & $21 \pm 1$ \\
$\mathbf{4}$ & $10.3 \pm 0.5$ & - & $24.6 \pm 1.5$ & $18.7 \pm 0.5$ \\
$\mathbf{2}$ & - & - & $22.6 \pm 1.6$ & $10.9 \pm 0.7$ \\
IZD of 1,10-phen & & & & \\
$\mathbf{8}$ & $33.0 \pm 0.7$ & $33 \pm 1$ & $36 \pm 0.6$ & $38.5 \pm 1.5$ \\
$\mathbf{4}$ & $21.6 \pm 0.5$ & $31.5 \pm 1.7$ & $33.6 \pm 0.7$ & $35.4 \pm 0.5$ \\
$\mathbf{2}$ & $11.0 \pm 1$ & $29.0 \pm 0.7$ & $24 \pm 1.6$ & $28.6 \pm 0.7$ \\
\hline
\end{tabular}

Tables 4 and 5 show that the complexation process of cobalt-sulindac with 1,10-phen in complex 3 decreased the anti-bacterial activity considerably for both gram negative and gram positive bacteria, but complexation of cobalt-sulindac with 2,9-dimephen in complex 4 mostly showed similar behavior against S. epidermidis and yeast, but decreased the activity against $S$. aureus and increased the anti-bacterial activity against gram negative bacteria. The anti-bacterial activity of complexes 1-4 when compared with previously reported work would be considered as promising results $[15,28-36,72-78]$.

\section{Conclusion}

Four new $\mathrm{Co}$ (II) complexes with sulindac in the presence of $\mathrm{N}$-donor heterocyclic ligands (2-ampy, 1,10-phen and 2,9-dimephen) have been synthesized and characterized. Magnetic properties, infrared and UV-Vis spectrophotometric techniques were used to study the new complexes in addition to X-ray diffraction of complexes $\mathbf{1}$ and 4; which reveals distorted octahedral geometry of the Co(II) ion. In complex 1 the cobalt binds two monodentate sulindac groups and in complex 4 cobalt binds two bidentate sulindac groups and one 2,9-dimephen. The structures of the remaining complexes were proposed depending on IR, UV-Vis results and magnetic properties. Complexes 3 and $\mathbf{4}$ showed anti-bacterial activity against $\mathrm{G}^{+}$and $\mathrm{G}^{-}$bacteria. Moreover, complex 4 have demonstrated the highest efficiency against yeast.

The results of this work was Submitted in Partial Fulfillment of the Requirements for the Degree of Masters in Applied Chemistry, Faculty of Graduate Studies, Birzeit University, Ramallah, Palestine. The thesis was published in 2015 on FADA Birzeit University Open Access Repository [79].

\section{Experimental}

\section{Starting materials}

Cobalt(II) chloride was purchased from Merck, sulindac, 2-aminopyridine, 1,10-phenanthroline and 2,9-dimethyl-1,10-phenanthroline were purchased from SigmaAldrich. All solvents used were of analytical reagent grade and purchased from commercial sources. E. coli, S. aureus, S. epidermidis, Bordetella and Yeast species (Saccharomyces and candida) were kindly obtained from the Drugs Department at Central Public Health Laboratory.

\section{Synthesis}

All $\mathrm{Co}(\mathrm{II})$ complexes were synthesized at room temperature in ambient conditions.

\section{Synthesis of $\left[\mathrm{Co}\left(\mathrm{H}_{2} \mathrm{O}\right)_{4}(\mathrm{sul})_{2}\right](1)$}

Sulindac $(3.0 \mathrm{~g}, 8.4 \mathrm{mmol})$ was allowed to dissolve in a methanolic solution of potassium hydroxide $(0.47 \mathrm{~g}$, $4.2 \mathrm{mmol}$ ) (75 ml methanol). To this solution was added slowly $\mathrm{CoCl}_{2} \cdot 7 \mathrm{H}_{2} \mathrm{O}(1.0 \mathrm{~g}, 4.2 \mathrm{mmol})$ in $15 \mathrm{ml}$ of methanol. The mixture was allowed to stir for $24 \mathrm{~h}$ and the formed precipitate was collected, washed with cold water and air dried. Suitable crystals for X-ray structural analysis were obtained by recrystallization from hot methanol.

$\left[\mathbf{C o}\left(\mathbf{H}_{2} \mathbf{O}\right)_{4}(\mathbf{s u l})_{2}\right](\mathbf{1}): 85 \%(3.81 \mathrm{~g})$ yield; m.p. $201{ }^{\circ} \mathrm{C}$; IR $\left(\mathrm{cm}^{-1}, \mathrm{KBr}\right): 3376,3050,2911,2850,1600,1563$,

Table 5 Comparison of anti-bacterial activity of complex 4 with 2,9-dimephen

\begin{tabular}{lllccc}
\hline Concentration $(\mathbf{m g} / \mathbf{m l})$ & $\begin{array}{l}\text { Bordetella } \\
\text { G- }\end{array}$ & $\begin{array}{l}\text { E. coli } \\
\text { G- }\end{array}$ & $\begin{array}{l}\text { S. epidermidis } \\
\text { G+ }\end{array}$ & $\begin{array}{l}\text { S. aureus } \\
\text { G+ }\end{array}$ & $\begin{array}{l}\text { Saccharomyces } \\
\text { Yeast }\end{array}$ \\
\hline IZD of $\mathbf{4}(\mathrm{mm})$ & & & & $25.0 \pm 1.5$ & $41.12 \pm 0.5$ \\
$\mathbf{8}$ & $16.2 \pm 1.9$ & $12.0 \pm 2.0$ & $39 \pm 1$ & $24.3 \pm 0.5$ & $41 \pm 1$ \\
$\mathbf{4}$ & $13.7 \pm 0.5$ & - & $34.6 \pm 0.7$ & $21.9 \pm 0.7$ & $35.9 \pm 0.5$ \\
$\mathbf{2}$ & $11.4 \pm 1.2$ & - & $30.4 \pm 1.6$ & $39 \pm 1$ & $44 \pm 2$ \\
IZD of $\mathbf{2 , 9 - d i m e p h e n}$ & & & & $35.4 \pm 0.5$ & $42 \pm 1$ \\
$\mathbf{8}$ & $14.6 \pm 0.9$ & - & $36.9 \pm 1.5$ & $31.3 \pm 0.7$ & $38.4 \pm 0.5$ \\
$\mathbf{4}$ & $9.2 \pm 0.5$ & - & $33.0 \pm 1.6$ & & \\
$\mathbf{2}$ & $8.3 \pm 1.2$ & - & & & \\
\hline
\end{tabular}


$1485,1465,1416,1369,1326,1268,1217,1203,1171$, 1133, 1086, 1024, 1008, 967, 918, 891, 891, 868, 805, 776, 717, 672, 659, 572, 473; UV-Vis [DMSO, $\lambda(\mathrm{nm})$ ( $\left.\epsilon / \mathrm{Lmol}^{-1} \mathrm{~cm}^{-1}\right)$ ]: 211 (3283), 252 (828), 258 (872), 264 (850), 282 (771), 328 (514); $\mu_{\text {eff }}=2.26$ BM.

\section{Synthesis of $\left[\mathrm{Co}(2-a m p y)_{2}(\mathrm{Sul})_{2}\right]$ (2)}

Sulindac (3.0 g, $8.4 \mathrm{mmol})$ was allowed to dissolve in a methanolic solution of potassium hydroxide (0.47 g, $4.2 \mathrm{mmol}$ ) (40 ml methanol). To this solution was added slowly $\mathrm{CoCl}_{2} \cdot 7 \mathrm{H}_{2} \mathrm{O}(1.0 \mathrm{~g}, 4.2 \mathrm{mmol})$ in $10 \mathrm{ml}$ of methanol, then 2-ampy $(0.79 \mathrm{~g}, 8.4 \mathrm{mmol})$ dissolved in $15 \mathrm{ml}$ of methanol was added. The mixture was allowed to stir for $24 \mathrm{~h}$, the solvent was evaporated then the residue was dissolved in dichloromethane which was then evaporated and the compound obtained was washed with petroleum ether and dried under vacuum.

$\left[\mathbf{C o}(2 \text {-ampy })_{2}(\mathbf{S u l})_{2}\right]$ (2): $56 \%\left(2.50\right.$ g) yield; m.p. $180{ }^{\circ} \mathrm{C}$ (decomposed); IR ( $\left.\mathrm{cm}^{-1}, \mathrm{KBr}\right): 3374,3268,3015,2914$,
2860, 1599, 1515, 1494, 1464, 1424, 1380, 1267, 1195, 1164, 1137, 1086, 1031, 1010, 955, 915, 891, 846, 811, 727, 651, 593, 533, 474, 449; UV-Vis [DMSO, $\lambda(\mathrm{nm})$; ( $\left.\epsilon / \mathrm{Lmol}^{-1} \mathrm{~cm}^{-1}\right)$ ]: 207 (1828), 286 (450), 329 (348), 655 (12.7); $\mu_{\mathrm{eff}}=2.41 \mathrm{BM}$.

\section{Synthesis of $\left[\mathrm{Co}\left(\mathrm{H}_{2} \mathrm{O}\right)_{2}(1,10-\right.$ phen $\left.)(\mathrm{sul})_{2}\right]$ (3)}

Sulindac (3.0 g, $8.4 \mathrm{mmol})$ was allowed to dissolve in a methanolic solution of potassium hydroxide (0.47 g, $4.2 \mathrm{mmol}$ ) (40 ml methanol). To this solution was added slowly $\mathrm{CoCl}_{2} \cdot 7 \mathrm{H}_{2} \mathrm{O}(1.0 \mathrm{~g}, 4.2 \mathrm{mmol})$ in $10 \mathrm{ml}$ of methanol, then 1,10 -phenanthroline $(0.756 \mathrm{~g}, 4.2 \mathrm{mmol})$ dissolved in $15 \mathrm{ml}$ of methanol was added. The mixture was allowed to stir for $24 \mathrm{~h}$, the solvent was evaporated then the residue was dissolved in dichloromethane which was then evaporated and the compound obtained was washed with petroleum ether and dried under vacuum.

[Co $\left(\mathrm{H}_{2} \mathrm{O}\right)_{2}(\mathbf{1}, \mathbf{1 0}$-phen $\left.)(\mathbf{s u l})_{2}\right]$ (3): $22 \%(1.0 \mathrm{~g})$ yield; m.p. $140{ }^{\circ} \mathrm{C}$; IR $\left(\mathrm{cm}^{-1}, \mathrm{KBr}\right): 3415,3059,2911,2852$,

Table 6 Structure refinement of crystal data for compounds (1) and (4)

\begin{tabular}{|c|c|c|c|c|}
\hline & Complex (1) & & Complex (4) & \\
\hline Empirical formula & $\mathrm{C}_{40} \mathrm{H}_{34} \mathrm{CoF}_{2} \mathrm{O}_{12} \mathrm{~S}_{2}$ & & $\mathrm{C}_{53} \mathrm{H}_{38} \mathrm{CoF}_{2} \mathrm{~N}_{2} \mathrm{O}_{5} \mathrm{~S}_{2}$ & \\
\hline Formula weight & 867.72 & & 943.90 & \\
\hline Wavelength & $0.71073 \AA$ & & $0.71073 \AA$ & \\
\hline Temperature & 295(1) K & & $295(1) K$ & \\
\hline Space group & $P-1$ & & $\mathrm{P} 2(1) / \mathrm{C}$ & \\
\hline Crystal system & Triclinic & & Monoclinic & \\
\hline \multirow[t]{3}{*}{ Unit cell dimensions } & $a=5.012(3) \AA$ & $a=81.85(1)^{\circ}$ & $a=20.930(3) \AA$ & $a=90^{\circ}$ \\
\hline & $b=12.640(8) \AA$ & $\beta=82.230(9)^{\circ}$ & $b=14.836(2) \AA$ & $\beta=101.705^{\circ}$ \\
\hline & $c=16.22(1) \AA$ & $Y=86.40(1)^{\circ}$ & $c=15.807(2) \AA$ & $Y=90^{\circ}$ \\
\hline Volume & $1006.9(11) \AA^{3}$ & & $4806.3(11) \AA^{3}$ & \\
\hline Z & 1 & & 4 & \\
\hline Absorption coefficient & $0.601 \mathrm{~mm}^{-1}$ & & $0.500 \mathrm{~mm}^{-1}$ & \\
\hline Density (calculated) & $1.431 \mathrm{Mg} / \mathrm{m}^{3}$ & & $1.304 \mathrm{Mg} / \mathrm{m}^{3}$ & \\
\hline Crystal size & $0.50 \times 0.16 \times 0.06 \mathrm{~mm}^{3}$ & & $0.53 \times 0.46 \times 0.05 \mathrm{~mm}^{3}$ & \\
\hline$F(000)$ & 447 & & 1948 & \\
\hline Reflections collected & 10,787 & & 52,864 & \\
\hline Theta range for data collection & $2.56-27.00^{\circ}$ & & $1.69-27.00^{\circ}$ & \\
\hline Index ranges & $-6 \leq h \leq 6,-16 \leq k \leq 16,-20 \leq 1 \leq 20$ & & $-26 \leq h \leq 26,-18 \leq k \leq 18,-20 \leq 1 \leq 19$ & \\
\hline $\begin{array}{l}\text { Completeness to } \\
\text { theta }=26.99^{\circ}\end{array}$ & $98.5 \%$ & & $99.7 \%$ & \\
\hline Independent reflections & $4334[\mathrm{R}(\mathrm{int})=0.0625]$ & & $10,468[R($ int $)=0.0766]$ & \\
\hline Absorption correction & None & & None & \\
\hline Data/restraints/parameters & $4334 / 0 / 273$ & & $10,468 / 0 / 603$ & \\
\hline Refinement method & Full-matrix least-squares on $\mathrm{F}^{2}$ & & Full-matrix least-squares on $\mathrm{F}^{2}$ & \\
\hline Largest diff. peak and hole & 1.331 and -0.664 e $\AA^{-3}$ & & 2.147 and -0.686 e $\AA^{-3}$ & \\
\hline Goodness-of-fit on $\mathrm{F}^{2}$ & 1.210 & & 1.576 & \\
\hline R indices (all data) & $R 1=0.1355, w R^{2}=0.2727$ & & $R 1=0.2349, w R^{2}=0.4718$ & \\
\hline Final R indices ${ }^{\mathrm{a}}[\mathrm{I}>2 \operatorname{sigma}(\mathrm{I})]$ & $R 1=0.1158, w R^{2}=0.2599$ & & $R 1=0.1941, w R^{2}=0.4496$ & \\
\hline
\end{tabular}

${ }^{\mathrm{a}} \mathrm{R} 1=\sum\left\|\mathrm{F}_{0}|-| \mathrm{F}_{\mathrm{c}}\right\| / \sum \mathrm{F}_{0}, \mathrm{WR}_{2}=\left\{\sum\left[\mathrm{W}\left(\mathrm{F}_{0}^{2}-\mathrm{F}_{\mathrm{c}}^{2}\right)^{2}\right] / \sum\left[\mathrm{W}\left(\mathrm{F}_{0}^{2}\right)^{2}\right\}^{1 / 2}\right.$ 
$1600,1515,1464,1424,1380,1267,1195,1164,1137$, 1086, 1010, 956, 915, 891, 846, 811, 727, 651, 593, 533, 474, 441; UV-Vis [DMSO, $\left.\lambda(\mathrm{nm})\left(\epsilon / \mathrm{Lmol}^{-1} \mathrm{~cm}^{-1}\right)\right]: 208$ (2152), 226 (700), 271 (535), 328 (224), 431 (16.3), 488 (13.2); $\mu_{\mathrm{eff}}=2.4 \mathrm{BM}$.

\section{Synthesis of $\left[\mathrm{Co}\left(2,9-\right.\right.$ dimephen)(sul) $\left.{ }_{2}\right]$ (4)}

Sulindac $(3.0 \mathrm{~g}, 8.4 \mathrm{mmol})$ was allowed to dissolve in a methanolic solution of potassium hydroxide $(0.47 \mathrm{~g}$, $4.2 \mathrm{mmol}$ ) (40 ml methanol). To this solution was added slowly $\mathrm{CoCl}_{2} \cdot 7 \mathrm{H}_{2} \mathrm{O}(1.0 \mathrm{~g}, 4.2 \mathrm{mmol})$ in $10 \mathrm{ml}$ of methanol, then 2,9-dimethyl-1,10-phenanthroline $(0.875 \mathrm{~g}$, $4.2 \mathrm{mmol}$ ) dissolved in $15 \mathrm{ml}$ of methanol was added. The mixture was allowed to stir for $24 \mathrm{~h}$, the solvent was evaporated then the residue was dissolved in dichloromethane which was then evaporated and the compound obtained was washed with petroleum ether and dried. Suitable crystals for X-ray structural analysis were obtained by recrystallization from 1:1 mixture of chloroform/acetonitrile.

[Co(2,9-dimephen)(sul) $)_{2}$ ] (4): $34 \%$ (1.54 g) yield; m.p. $150{ }^{\circ} \mathrm{C}$ (decomposed); IR ( $\left.\mathrm{cm}^{-1}, \mathrm{KBr}\right): 3040,2912,2845$, 1599, 1566, 1465, 1441, 1359, 1194, 1157, 1135, 1086, 1031, 954, 916, 891, 855, 812, 761, 728, 644, 533, 474; UV-Vis [DMSO, $\lambda(\mathrm{nm})\left(\epsilon / \mathrm{Lmol}^{-1} \mathrm{~cm}^{-1}\right)$ ]: 207 (2263), 229 (933), 274 (621), 328 (261), 432 (13.3); $\mu_{\mathrm{eff}}=2.4 \mathrm{BM}$.

\section{Physical measurements}

Infrared (IR) spectra were recorded in the 450$4000 \mathrm{~cm}^{-1}$ region $(\mathrm{KBr})$ on a Perkin Elmer FT-IR spectrometer (2004). UV-Vis spectra were recorded using Hewlett Packard 8453 photo diode array spectrophotometer in the $200-800 \mathrm{~nm}$ region using DMSO as solvent. Melting points were determined in capillary tubes with B-545 melt apparatus without any correction. The magnetic susceptibility measurements were determined by Gouy method using mercury cobalt-thiocyanate complex, $\left(\mathrm{HgCo}(\mathrm{NSC})_{4}\right)$ as standard. Calculation of the effective magnetic moment was obtained by using the following: $\mu_{\text {eff }}=2.83 *\left(\chi_{m} T\right)^{1 / 2}$ (Molar susceptibility, $X_{m}$, and $\mathrm{T}$ is the temperature with $\mathrm{K}$ ).

\section{X-ray crystallography}

$\mathrm{X}$-ray intensity data of complexes $\mathbf{1}$ and $\mathbf{4}$ was carried out at room temperature on a Bruker SMART APEX CCD $\mathrm{X}$-ray diffractometer system (graphite-monochromated Mo K $\alpha$ radiation $\lambda=0.71073 \AA$ ) by using the SMART software package [80]. The data were reduced and integrated by the SAINT program package [81]. The structure was solved and refined by the SHELXTL software package [82]. $\mathrm{H}$ atoms were located geometrically and treated with a riding model. The R-factor above $10 \%$ reflects the low quality of crystals obtained in the process of recrystallization and better crystals could not been found. Crystal data and details of the data collection and refinement are summarized in Table 6 and in Additionalfile 5: Supplementary crystallographic data for complexes $\mathbf{1}$ and $\mathbf{4}$.

\section{Anti-bacterial activity}

Agar diffusion method [83] was used for screening the anti-bacterial activity measurements of the synthesized cobalt complexes. Different types of gram-negative bacteria (Bordetella, E. coli) and gram-positive (S. epidermidis, S. aureus) and Yeast species (Saccharomyces and Candida) were used in the present work.

In sterile saline single bacterial colonies were dissolved until the suspended cells reached the turbidity of McFarland 0.5 Standard. The bacterial inocula were spread on the surface of the Muller Hinton nutrient agar by means of a sterile cotton swab. Sterile glassy borer were used to make a $6 \mathrm{~mm}$ in diameter wells in the agar plate. Samples were dissolved in DMSO in concentration equal to $(8 \mathrm{mg} / \mathrm{ml}),(4 \mathrm{mg} / \mathrm{ml})$ and $(2 \mathrm{mg} / \mathrm{ml})$, then $50 \mu \mathrm{l}$ of the test samples were introduced in the respective wells. DMSO was used as negative control while gentamycin used as positive control. Immediately the plate was incubated at $37^{\circ} \mathrm{C}$ for $24 \mathrm{~h}$. The anti-bacterial activity was determined by measuring the diameter inhibition zone of complete growth in millimeter $(\mathrm{mm})$. The averages of two trials determined the results and are stated as average \pm standard deviation.

\section{Additional files}

Additional file 1: Table S1. Physical properties and yield of Cobalt(II) sulindac compounds.

Additional file 2: Table S2. Comparison between some of principle peaks in IR for $\mathrm{K}(\mathrm{sul})$ and $1\left(\mathrm{Cm}^{-1}\right)$.

Additional file 3: Table S3. Summary of principle peaks in IR for complexes 2, 3 and $4\left(\mathrm{~cm}^{-1}\right)$.

Additional file 4: Table S4. UV-visible spectral data for compounds (1-4).

Additional file 5: CCDC 1450310 and CCDC 1450311 contain the supplementary crystallographic data for complexes 1 and 4 . These data can be obtained free of charge via http://www.ccdc.cam.ac.uk/conts/retrieving. html, or from the Cambridge Crystallographic Data Centre, 12 Union Road, Cambridge CB2 1EZ, UK; fax: (+44) 1223-336-033; or e-mail: deposit@ccdc. cam.ac.uk. Supplementary data associated with this article can be found, in the online version.

Authors' contributions

Both authors read and approved the final manuscript.

Acknowledgements

The authors thank the office of Vice President for Academic Affairs at Birzeit University for their financial support.

Competing interests

The authors declare that they have no competing interests. 


\section{Publisher's Note}

Springer Nature remains neutral with regard to jurisdictional claims in published maps and institutional affiliations.

Received: 1 March 2017 Accepted: 3 May 2017

Published online: 10 May 2017

\section{References}

1. Zhang KL, Lin JG, Wang YQ, Xu WL, Chen JT (2004) Aquabis (2-nitrobenzoato-kO)(1, 10-phenanthroline-k2N, N') zinc (II). Acta Crystallogr Sect C 60:m454-m456

2. Cotton FA, Wilkinson G, Murillo CA, Bochmann M (1999) Advanced inorganic chemistry, 6th edn. Wiley, New York, pp 817-819

3. Weder JE, Dillon CT, Hambley TW, Kennedy BJ, Lay PA, Biffin JR, Regtop HL, Davies NM (2002) Copper complexes of non-steroidal anti-inflammatory drugs: an opportunity yet to be realized. Coord Chem Rev 232:95

4. Ott I, Kircher B, Gust R (2004) Investigations on the effects of cobaltalkyne complexes on leukemia and lymphoma cells: cytotoxicity and cellular uptake. J Inorg Biochem 98:485-489

5. Yesilel OZ, Mutlu A, Darcan C, Buyukgungor O (2010) Syntheses, structural characterization and antimicrobial activities of novel cobalt-pyrazine-2, 3-dicarboxylate complexes with N-donor ligands. J Mol Struct 964:39-46

6. Lopez-Sandoval H, Londono-Lemos ME, Garza-Velasco R, PoblanoMelendez I, Granada-Macias P, Gracia-Mora I, Barba-Behrens N (2008) Synthesis, structure and biological activities of cobalt (II) and zinc (II) coordination compounds with 2-benzimidazole derivatives. J Inorg Biochem 102:1267-1276

7. Lv J, Liu T, Cai S, Wang X, Liu L, Wang Y (2006) Synthesis, structure and biological activity of cobalt (II) and copper (II) complexes of valine-derived schiff bases. J Inorg Biochem 100:1888-1896

8. Gust R, Ott I, Posselt D, Sommer K (2004) Development of cobalt (3, 4-diarylsalen) complexes as tumor therapeutics. J Med Chem 47:5837-5846

9. Dimiza F, Papadopoulos AN, Tangoulis V, Psycharis V, Raptopoulou CP, Kessissoglou DP, Psomas G (2010) Biological evaluation of non-steroidal antiinflammatory drugs-cobalt (II) complexes. Dalton Trans 39:4517-4528

10. Miodragovic DU, Bogdanovic GA, Miodragovic ZM, Radulovic MD, Novakovic SB, Kaluderovic GN, Kozlowski H (2006) Interesting coordination abilities of antiulcer drug famotidine and antimicrobial activity of drug and its cobalt (III) complex. J Inorg Biochem 100:1568-1574

11. Nomiya K, Yoshizawa A, Tsukagoshi K, Kasuga NC, Hirakawa S, Watanabe J (2004) aluminium (III) and cobalt (II) complexes with 4-isopropyltropolone (hinokitiol) showing noteworthy biological activities. Action of silver (I)-oxygen bonding complexes on the antimicrobial activities. J Inorg Biochem 98:46-60

12. Rodriguez-Argüelles MC, Mosquera-Vazquez S, Sanmartin-Matalobos J, Garcia-Deibe AM, Pelizzi C, Zani F (2010) Polyhedron 29:864-866

13. Matsumoto K, Yamamoto S, Yoshikawa Y, Doe M, Kojima Y, Sakurai H, Hashimoto H, Kajiwara MN (2005) Antidiabetic activity of Zn (II) complexes with a derivative of L-glutamine. Bull Chem Soc Jpn 78:1077-1081

14. Dorkov P, Pantcheva IN, Sheldrick WS, Mayer-Figge H, Petrova R, Mitewa M (2008) Synthesis, structure and antimicrobial activity of manganese (II) and cobalt (II) complexes of the polyether ionophore antibiotic Sodium Monensin A. J Inorg Biochem 102:26-32

15. Abu Ali H, Darawsheh MD, Rappocciolo E (2013) Synthesis, crystal structure, spectroscopic and biological properties of mixed ligand complexes of zinc (II) valproate with 1, 10-phenanthroline and 2-aminomethylpyridine. Polyhedron 61:235-241

16. Szunyogova E, Gyoryova K, Hudecova D, Piknova L, Chomic J, Vargova Z, Zelenak V (2007) Thermal, spectral and biological properties of Zn (II) complex compounds with phenazone. J Therm Anal Calorim 88:219-223

17. Rodriguez-Arguelles MC, Mosquera-Vazquez S, Sanmartin-Matalobos J, Garcia-Deibe AM, Pelizzi C, Zani F (2010). Polyhedron: 867-870

18. Fountoulaki S, Perdih F, Turel I, Kessissoglou DP, Psomas G (2011) Non-steroidal anti-inflammatory drug diflunisal interacting with $\mathrm{Cu}$ (II). Structure and biological features. J Inorg Biochem. 105:1645-1655

19. Hwu JR, Tsay SC, Chuang KS, Kapoor M, Lin JY, Yeh CS, Su WC, Wu PC, Tsai TL, Wang PW, Shieh DB (2016) Syntheses of platinum-sulindac complexes and their nanoparticles as targeted anticancer drugs. Chem-A Eur J. 22:1926-1930

20. Dimiza F, Papadopoulos A, Tangoulis V, Raptopoulou C, Kessissglou D, Psomas G (2012) Biological evaluation of cobalt (II) complexes with nonsteroidal anti-inflammatory drug naproxen. J Inorg Biochem 107:54-64

21. Tsiliou S, Kefala L, Perdih F, Turel I, Kessissoglou D, Psomas G (2012) Cobalt (II) complexes with non-steroidal anti-inflammatory drug tolfenamic acid: Structure and biological evaluation. Eur J Med Chem 48:132-142

22. Tsiliou S, Kefala Hatzidimitriou A, Kessissoglou D, Perdih F, Papadopoulos A, Turel I, Psomas G (2015) J Inorg Biochem: 1-15

23. Psomas G, Kessissoglou D (2013) Dalton Trans: 1-52

24. Patil A, Donde K, Raut S, Patil V, Lokhande R (2012) J Chem Pharm Res 4:1413-1425

25. Kovala-Demertzi D (2000) J Inorg Biochem 79:153-157

26. Krstic NS, Nikolic RS, Stankovic MN, Nikolic NG, Dordevic DM (2015) Coordination compounds of $\mathrm{M}$ (II) biometal lons with acid-type antiinflammatory drugs as ligands_-a review. Trop J Pharm Res 14:337-349

27. Konstandinidou M, Kourounakis A, Yiangou M, Hadjipetrou L, KovalaDemertzi D, Hadjikakou S, Demertzis M (1998) Anti-inflammatory properties of diclofenac transition metalloelement complexes. J Inorg Biochem 70:63-69

28. Abu Ali H, Fares H, Darawsheh M, Rappocciolo E, Akkawi M, Jaber S (2015) Synthesis, characterization and biological activity of new mixed ligand complexes of Zn (II) naproxen with nitrogen based ligands. Eur J Med Chem 89:67-76

29. Darawsheh M, Abu Ali H, Abuhijleh AL, Rappocciolo E, Akkawi M, Jaber S, Maloul S, Hussein Y (2014) New mixed ligand zinc (II) complexes based on the antiepileptic drug sodium valproate and bioactive nitrogen-donor ligands. Synthesis, structure and biological properties. Eur J Med Chem 82:152-163

30. Abu Ali H, Jabali B (2016) Polyhedron 107:97-106

31. Jabali B, Abu Ali H (2016) Non-steroidal Anti-Inflammatory Drug (indomethacin) and various nitrogen donor ligands. Synthesis, characterization and biological activity. Polyhedron 117:249-258

32. Abu Ali H, Omar S, Darawsheh M, Fares H (2016) Synthesis, characterization and antimicrobial activity of zinc (II) ibuprofen complexes with nitrogen-based ligands. J Coord Chem 69:1110-1122

33. Abu Ali H, Maloul S, Abu Ali l, Akkawi M, Jaber S (2016) Dichloro-bis(pyridine-2-yl-undecyl-amine) zinc (II), [ZnCl2 (C16N2H26) 2]: Synthesis, characterization and antimalarial activity. J Coord Chem 69:2514-2522

34. Abu Ali H, Shalash A, Akawi M, Jaber S (2017) Synthesis, characterization and in vitro biological activity of new zinc (II) complexes of the nonsteroidal anti-inflammatory drug sulindac and nitrogen-donor ligands. Appl Organomet Chem. doi:10.1002/aoc.3772

35. Abu Ali H, Kamel S, Abu Shamma A (2017) Novel structures of Zn (II) biometal cation with the biologically active substituted acetic acid and nitrogen donor ligands: Synthesis, spectral, phosphate diester catalytic hydrolysis and anti-microbial studies. Appl Organomet Chem. doi:10.1002/aoc.3829

36. Abu Ali H, Abu Shamma A, Kamel S (2017) New mixed ligand cobalt (II/III) complexes based on the drug sodium valproate and bioactive nitrogendonor ligands. Synthesis, structure and biological properties. J Mol Struct. doi:10.1016/j.molstruc.2017.04.048

37. http://en.wikipedia.org/wiki/Sulindac. Accessed 20 Jan 2015

38. www.wiley-vch.de/books/sample/3527331476_c01.pdf. Accessed 15 Mar 2015

39. Viossat V, Lemoine P, Dayan E, Dung N, Viossat B (2005) Synthesis, crystal structures and IR spectra of isotypic pseudopolymorphs complexes of Zn (II) by indole-2-carboxylic acid and 2, 9-dimethyl-1, 10-phenanthroline with different solvates (DMA, DMF or DMSO). J Mol Struct 741:45-52

40. Kadhiravan S, Sivajiganesan S (2015) J Appl Chem 8:73-84

41. Waizump K, Takuno M, Fukushima N, Masuda H (1998) Structures of pyridine carboxylate complexes of cobalt (II) and copper (II). J Coord Chem 44:269-279

42. Liu Z, Chen Y, Liu P, Wang J, Huang M (2005) Cadmium (II) and cobalt (II) complexes generated from benzimidazole-5-carboxylate: selfassembly by hydrogen bonding and $\pi-\pi$ interactions. J Solid State Chem $178: 2306-2312$

43. Bu XH, Tong ML, Xie YB, Li JR, Chang HC, Kitagawa S, Ribas J (2005) Synthesis, structures, and magnetic properties of the copper (II), cobalt 
(II), and manganese (II) complexes with 9-acridinecarboxylate and 4-quinolinecarboxylate ligands. Inorg Chem 44:9837-9846

44. Rettig SJ, Thompson RC, Trotter J, Xia S (1999) rystal structure and magnetic properties of polybis (formamide) bis ( $\mu$-formato) cobalt (II): an extended two-dimensional square lattice material which exhibits spontaneous magnetization below 9 K. Inorg Chem 38:1360-1363

45. Greiner BA, Marshall NM, Narducci Sarjeant AA, McLauchlan CC (2007) Imidazole-based nickel (II) and cobalt (II) coordination complexes for potential use as models for histidine containing metalloproteins. Inorg Chim Acta 360:3132-3140

46. Singh UP, Aggarwal V, Sharma AK (2007) Mononuclear cobalt (II) carboxylate complexes Synthesis molecular structure and selective oxygenation study. Inorg Chim Acta 360:3226-3232

47. Khandar AA, Shaabani B, Belaj F, Bakhtiari A (2007) Synthesis, characterization, electrochemical and spectroscopic investigation of cobalt (III) Schiff base complexes with axial amine ligands: The layered crystal structure of [Co III (salophen)(4-picoline) 2] ClO 4. CH $2 \mathrm{Cl}$ 2. Inorg Chim Acta 360:3255-3264

48. Lai CS, Tiekink ERT (2003) Appl Organomet Chem 17:255-256

49. Nakamoto K (2009) Infrared and Raman spectra of inorganic and coordination compounds, 6th edn. Wiley, Hoboken

50. Badshah KD (2011) Synthesis and characterization of zinc complexes with $\mathrm{N}$ - and O- donor ligands. AIOU, Islamabad

51. Zeleňák V, Vargová Z, Györyová K (2007) Correlation of infrared spectra of zinc (II) carboxylates with their structures. Spectrochim Acta, Part A 66:262-272

52. Zhang X, Yi ZH, Xue M, Xu Y, Yu JH, Yu XY, Xu JQ (2007) Chem Res Chin Univ 23:631-634

53. Yu HL, Yang J, Fu Q, Ma JC, Li WL (2008) Chem Res Chin Univ 24:123

54. Hasanvanda F, Hoseinzadeh A, Zolgharnein J, Amania S (2010) J Coord Chem 63:346-352

55. Ahmadia RA, Hasanvanda F, Brunob G, Rudbarib HA, Amania S (2013) Russ J Coord Chem 39:867-871

56. Komaei SA, Albada G, Reedijk AV (1999) J Trans Met Chem 24:104-107

57. Rodríguez L, Labisbal E, Sousa-Pedrares A, García-Vázquez JA, Romero J, Durán ML, Real A, Sousa A (2006) Coordination chemistry of amine bis (phenolate) cobalt (II), nickel (II), and copper (II) complexes. Inorg Chem 45:7903-7914

58. Shaker SA, Farina Y, Mahmmod S, Eskender M (2009) Co (II), Ni (II), Cu (II), Zn (II) and Cd (II) mixed ligand complexes of theophylline and cyanate: synthesis and spectroscopic characterization. Mod Appl Sci 3:88-93

59. Sunita Devi O, Manihar Singh AK (2011) J Chem Pharm Res 3:1055-1060

60. Al-Nahary TT (2009) Synthesis and characterization of metal complexes of Cr (III), Mn (II), Fe (III), Co (II), Ni (II), Cu (II), Ru (III), Rh (III) and Pd (II) with derivatives of 1, 3, 4-thiadiazole-2, 5-dithiol as new ligands. J Saudi Chem Soc 13:253-257

61. Al-Nahary TT (2007) ISESCO J Sci Technol Vis 3:16-22

62. Faus J, Julve M, Lloret F, Muiioz MC (1993) Bis (dimethylviolurato)(phenanthroline) cobalt (II), a low-spin octahedral cobalt (II) complex. Crystal structure of [Co (dmvi) 2phen]. 2CHCl3. Inorg Chem 32:2013-2017
63. Çukurovali A, Yilmaz I, Özmen H, Ahmedzade M (2002) Cobalt (II), copper (II), nickel (II) and zinc (II) complexes of two novel Schiff base ligands and their antimicrobial activity. Trans Met Chem 27:171-176

64. Pal S, Sengupta P, Ghosh S, Mukherjee G, Mostafa G (2002) Cobalt (III) and Low Spin Cobalt (II) Complexes of the Two Highly Flexible Hexadentate Ligands 1, 3-di (o-salicylaldiminophenylthio) propane and 1, 2-di (o-salicylaldiminophenylthio) xylene. J Coord Chem 55:271-280

65. Hitchman MA (1977) Electronic structure of low-spin cobalt (II) Schiff base complexes. Inorg Chem 16:1985-1993

66. Hartman JR, Hintsa EJ, Cooper SR (1986) J Am Chem Soc 108:1202-1208

67. Marques LF, Marinho MV, Speziali NL, Visentin LC, Machado FC (2011) Inorg Chim Acta 365:454-457

68. Bertrand JA, Carpenter DA, Kalyanaraman AR (1971) The structure of $\mathrm{K} 2 \mathrm{BaCO}(\mathrm{NO} 2) 6$ at $233^{\circ} \mathrm{K}$.: a static Jahn-Teller distortion. Inorg Chim Acta 5:113-114

69. Hartman JR, Hintsa EJ, Cooper SR (1984) J Chem Soc Chem Commun: 287-386

70. Setzer WN, Ogle CA, Wilson GS, Glass RS (1983) Inorg Chem 22:266-271

71. Wilson GS, Swanson DD, Glass RS (1986) Inorg Chem 25:3827

72. Dimiza F, Perdih F, Tangoulis V, Turel I, Kessissoglou DP, Psomas G (2012) Eur J Med Chem 48:132-142

73. Tsiliou S, Kefala LA, Perdih F, Turel I, Kessissoglou DP, Psomas G (2013) Dalton Trans 42:6252-6276

74. Psomas G, Kessissoglou DP (2002) J Enzyme Inhib Med Chem 17:87-91

75. Chohan ZH, lqbal MS, Iqbal HS, Scozzafava A, Supuran CT (2012) Eur J Med Chem 48:132-142

76. Tsiliou S, Kefala LA, Perdih F, Turel I, Kessissoglou DP, Psomas G (2012) J Inorg Biochem 107:54-64

77. Geraghtya M, Sheridana V, McCanna M, Devereuxb M, McKeec V (1999) Polyhedron 18:2931-2939

78. Podunavac-Kuzmanovic S, Vojinovic L, Cvetkovic D (2003) ISIRR

79. Shalash A, Abu Ali H (2015) Non-steroidal Zn(II) and Co(II) sulindac drugs and bioactive Nitrogen-donor ligands: synthesis, characterization, antibacterial effect, anti-malarial effect and the use as phosphate hydrolyzing enzymes, Master Thesis, Birzeit University

80. SMART-NT V5.6, B. A. G. (2002) Karlsruhe

81. SAINTL-NT V5.0, B. A. G. (2002) Karlsruhe

82. SHELXTL-NT V6.1, B. A. G. (2002) Karlsruhe

83. Rahman A, Choudhary MI, Thomsen WJ (2001) Bioassay techniques for drug development. Harwood Academic, Amsterdam

\section{Submit your manuscript to a SpringerOpen ${ }^{\circ}$ journal and benefit from:}

- Convenient online submission

- Rigorous peer review

- Immediate publication on acceptance

- Open access: articles freely available online

- High visibility within the field

- Retaining the copyright to your article

Submit your next manuscript at $\boldsymbol{\nabla}$ springeropen.com 